\title{
Bacillus iranensis sp. nov., a moderate halophile from a hypersaline lake
}

\author{
Correspondence \\ M. A. Amoozegar \\ amoozegar@ibrc.ir or \\ amozegar@khayam.ut.ac.ir
}

\author{
M. Bagheri, ${ }^{1,2}$ M. Didari, ${ }^{1}$ M. A. Amoozegar, ${ }^{2}$ P. Schumann, ${ }^{3}$ \\ C. Sánchez-Porro, ${ }^{4}$ M. Mehrshad ${ }^{1}$ and A. Ventosa ${ }^{4}$ \\ ${ }^{1}$ Microorganisms Bank, Iranian Biological Resource Centre (IBRC), ACECR, Teheran, Iran \\ ${ }^{2}$ Extremophiles Laboratory, Department of Microbiology, Faculty of Biology, College of Science, \\ University of Tehran, Tehran, Iran \\ ${ }^{3}$ DSMZ-German Collection of Micro-organisms and Cell Cultures, Inhoffenstrasse 7B, \\ 3814 Braunschweig, Germany \\ ${ }^{4}$ Department of Microbiology and Parasitology, Faculty of Pharmacy, University of Sevilla, \\ 41012 Sevilla, Spain
}

\begin{abstract}
A Gram-positive, moderately halophilic rod, designated $X 5 \mathrm{~B}^{\top}$, was isolated from saline mud of the hypersaline lake Aran-Bidgol in Iran. Strain $\mathrm{X} \mathrm{B}^{\top}$ was a strictly aerobic, motile bacterium that produced ellipsoidal endospores at a central-subterminal position in non-swollen sporangia. The isolate grew at $\mathrm{pH} 7.0-10.0$ (optimum pH 7.5), at $25-45{ }^{\circ} \mathrm{C}$ (optimum $35^{\circ} \mathrm{C}$ ) and with 2.5-15\% (w/v) NaCl (optimum 5-7.5\%). On the basis of 16S rRNA gene sequences, strain $\mathrm{X} \mathrm{B}^{\top}$ belonged to the genus Bacillus and showed highest similarity with Bacillus persepolensis $\mathrm{HS}_{136}{ }^{\top}$ (95.6\% 16S rRNA gene sequence similarity) and Bacillus salarius $\mathrm{BH}^{2} \mathrm{C}^{\top}$ (95.5\%). The DNA G $+C$ content was 42.4 mol\%. The major cellular fatty acids were anteiso- $\mathrm{C}_{15: 0}$ and iso- $\mathrm{C}_{15: 0}$ and the polar lipid profile consisted of phosphatidylglycerol, diphosphatidylglycerol, three phospholipids and two glycolipids. The diamino acid found in the cell-wall peptidoglycan was meso-diaminopimelic acid and the isoprenoid quinones were MK-7 (92\%), MK-6 (6\%) and MK-5 (2\%). On the basis of phylogenetic, chemotaxonomic and phenotypic data, a novel species of the genus Bacillus is proposed, with the name Bacillus iranensis sp. nov. The type strain is $\mathrm{X}^{\mathrm{B}} \mathrm{B}^{\mathrm{T}}$ (=IBRC $\left.10446^{\mathrm{T}}=\mathrm{DSM} 23995^{\mathrm{T}}\right)$.
\end{abstract}

Moderately halophilic bacteria are represented by physiologically and taxonomically heterogeneous groups that include both Gram-negative and Gram-positive microorganisms (Ventosa et al., 1998; Ventosa, 2006). Among the Gram-positive organisms, several aerobic, endosporeforming, halophilic genera and species have been reported (Arahal \& Ventosa, 2002; Ventosa, 2006; de la Haba et al., 2011). These bacteria are frequently isolated from saline and hypersaline environments such as soils and aquatic habitats (Arahal \& Ventosa, 2002; Ventosa, 2006; Márquez et al., 2011), are characterized by optimal growth in media containing 3-15\%(w/v) $\mathrm{NaCl}$ (Ventosa et al., 1998) and belong to species of the genus Bacillus or other Bacillusrelated genera (de la Haba et al., 2011). Studies of such bacteria are of great importance as they may produce compounds of industrial interest, such as extracellular hydrolytic enzymes that have diverse potential uses in

The GenBank/EMBL/DDBJ accession number for the 16S rRNA gene sequence of strain $X 5 B^{\top}$ is $\mathrm{HQ} 433452$.

Three supplementary figures are available with the online version of this paper. biotechnological processes (Margesin \& Schinner, 2001; Mellado \& Ventosa, 2003; Sánchez-Porro et al., 2003; Amoozegar et al., 2008; Kiran \& Chandra, 2008; Rohban et al., 2009; Karbalaei-Heidari et al., 2009; Shafiei et al., 2010).

During the study of the microbial population in hypersaline lakes in Iran, an aerobic, Gram-positive, moderately halophilic bacterium, designated strain $\mathrm{X} 5 \mathrm{~B}^{\mathrm{T}}$, was isolated from mud of the hypersaline lake Aran-Bidgol, the largest playa in the centre of Iran, $1000 \mathrm{~km}$ distant from the coast and at an altitude of $800 \mathrm{~m}$ (sampling site: $34.64378^{\circ} \mathrm{N}$ $51.83838^{\circ} \mathrm{E}$ ). This playa was formed by deposition of halite sediments in different geological periods. Most salts in this lake are $\mathrm{NaCl}, \mathrm{Na}_{2} \mathrm{SO}_{4}, \mathrm{MgCl}_{2}$ and $\mathrm{MgSO}_{4}$ and there are traces of carbonate ions. The $\mathrm{pH}$ of the water of the lake is neutral (about $\mathrm{pH}$ 7.0-7.5) and its salinity reaches saturation.

Strain $\mathrm{X}_{5 \mathrm{~B}}^{\mathrm{T}}$ was isolated by diluting the mud sample in sterile $10 \%(\mathrm{w} / \mathrm{v})$ salt solution, plating onto $7.5 \% \mathrm{HM}$ agar (containing $\mathrm{l}^{-1}$ : $60.75 \mathrm{~g} \mathrm{NaCl}, 5.25 \mathrm{~g} \mathrm{MgCl}_{2} \cdot 6 \mathrm{H}_{2} \mathrm{O}, 7.2 \mathrm{~g}$ $\mathrm{MgSO}_{4} \cdot 7 \mathrm{H}_{2} \mathrm{O}, 0.27 \mathrm{~g} \mathrm{CaCl}_{2} \cdot 2 \mathrm{H}_{2} \mathrm{O}, 1.5 \mathrm{~g} \mathrm{KCl}, 0.045 \mathrm{~g}$ $\mathrm{NaHCO}_{3}, 0.0195 \mathrm{~g} \mathrm{NaBr}, 5$ g proteose-peptone no. 3, $10 \mathrm{~g}$ 
yeast extract, $1 \mathrm{~g}$ glucose, $20 \mathrm{~g}$ agar; $\mathrm{pH}$ 7.5; Ventosa et al., 1982) and incubating at $35^{\circ} \mathrm{C}$ under aerobic conditions. The isolate was subsequently purified three times and maintained on the same medium and was stored in $7.5 \% \mathrm{HM}$ broth supplemented with $30 \%(\mathrm{v} / \mathrm{v})$ glycerol at $-80{ }^{\circ} \mathrm{C}$.

In order to phenotypically characterize strain $\mathrm{X}_{5} \mathrm{~B}^{\mathrm{T}}$, the recently published minimal standards for describing new taxa of aerobic, endospore-forming bacteria were followed (Logan et al., 2009). Unless stated otherwise, the morphological, physiological and biochemical characteristics of the isolate were studied in $7.5 \% \mathrm{HM}$ broth at $\mathrm{pH} 7.5$ and $35^{\circ} \mathrm{C}$. Bacillus persepolensis IBRC $10436^{\mathrm{T}}$ and Bacillus salarius DSM $16461^{\mathrm{T}}$ were obtained from the IBRC and DSMZ culture collections, cultured under the same growth conditions as strain $\mathrm{X} 5 \mathrm{~B}^{\mathrm{T}}$ and used as reference strains.

Cell morphology was examined by light microscopy (model CX31-2; Olympus) using cells from exponentially growing cultures. Gram-staining was performed by the Burke method (Murray et al., 1994) and the result was confirmed by the KOH test (Baron \& Finegold, 1990). The presence of endospores was investigated by the Schaeffer-Fulton staining method (Murray et al., 1994). Motility was analysed by the wet-mount method (Murray et al., 1994). Catalase, oxidase and urease activities, nitrate reduction, aesculin hydrolysis, indole production and methyl red and Voges-Proskauer tests were done as recommended by Smibert \& Krieg (1994). Hydrolysis of Tweens 40, 60 and 80 was examined as described by Harrigan \& McCance (1976). Determination of acid production from carbohydrates, as well as utilization of carbon and energy sources, was performed as recommended by Ventosa et al. (1982). Antibiotic susceptibility tests were performed using discs impregnated with various antimicrobial compounds (HiMedia) on Mueller-Hinton agar plus $7.5 \%(\mathrm{w} / \mathrm{v})$ sea salts (Ventosa et al., 1982) seeded with a bacterial suspension containing $1.5 \times 10^{6}$ c.f.u. $\mathrm{ml}^{-1}$. The plates were incubated at $35{ }^{\circ} \mathrm{C}$ for $48 \mathrm{~h}$ and inhibition zones were interpreted according to the manufacturer's instructions. Growth at $10-50{ }^{\circ} \mathrm{C}$ (at intervals of $5{ }^{\circ} \mathrm{C}$ ) and at pH 5-11 (at intervals of $0.5 \mathrm{pH}$ unit) was determined in nutrient broth supplemented with $7.5 \%(\mathrm{w} / \mathrm{v}) \mathrm{NaCl}$, with the $\mathrm{pH}$ adjusted using the following buffer systems, as recommended by Amoozegar et al. (2009): sodium acetate/ acetic acid $(\mathrm{pH}<6)$, Tris/ $\mathrm{HCl}(\mathrm{pH} 6-9)$ and glycine/ sodium hydroxide $(\mathrm{pH}>9)$. Growth with $0,2.5,5,7.5$, $10,15,20,25$ and $30 \%(\mathrm{w} / \mathrm{v}) \mathrm{NaCl}$ was tested in HM broth at $\mathrm{pH}$ 7.5. Growth was monitored by measuring turbidity at $A_{600}$ (model UV-160 A; Shimadzu). Other physiological and biochemical tests were performed as described elsewhere (Mata et al., 2002; Quesada et al., 1984; Ventosa et al., 1982).

Strain $\mathrm{X}_{5 \mathrm{~B}}{ }^{\mathrm{T}}$ was Gram-positive, motile and strictly aerobic. Ellipsoidal endospores were formed at the central-subterminal position in non-swollen sporangia. Cells were rods (0.5-0.9 $\mu \mathrm{m}$ wide and 1.2-2.5 $\mu \mathrm{m}$ long). After growth for 2 days at $35{ }^{\circ} \mathrm{C}$ on $7.5 \% \mathrm{HM}$ agar, colonies were circular, entire, smooth, cream and $2 \mathrm{~mm}$ in diameter. The isolate was moderately halophilic and grew in media containing
2.5-15\% (w/v) $\mathrm{NaCl}$ (optimum 5.0-7.5\%). No growth was observed in the absence of $\mathrm{NaCl}$. Strain $\mathrm{X} 5 \mathrm{~B}^{\mathrm{T}}$ grew at $\mathrm{pH}$ 7.0-10.0 (optimum pH 7.5). Other phenotypic features are included in Table 1 and the species description.

Genomic DNA from strain $\mathrm{X}_{5} \mathrm{~B}^{\mathrm{T}}$ was prepared using the method described by Marmur (1961). The 16S rRNA gene was amplified by PCR with the forward primer 16F27 and the reverse primer 16R1488 as described by Mellado et al. (1995). Direct sequence determination of the amplified DNA was carried out using an automated DNA sequencer (ABI $3130 \mathrm{XL}$; Applied Biosystems) at the SeqLab Laboratory (Göttingen, Germany). An almost-complete $16 \mathrm{~S}$ rRNA gene sequence (1439 bp) of strain $\mathrm{X}^{\mathrm{B}} \mathrm{B}^{\mathrm{T}}$ was obtained and used for initial BLAST searches in GenBank

Table 1. Characteristics that distinguish strain $X 5 B^{\top}$ from its closest phylogenetic neighbours

Strains: 1, Bacillus iranensis sp. nov. $\mathrm{X}^{\mathrm{T}} \mathrm{B}^{\mathrm{T}} ; 2$, B. persepolensis IBRC $10436^{\mathrm{T}}$; 3, B. salarius DSM $16461^{\mathrm{T}}$. Data were taken from this study unless otherwise indicated.

\begin{tabular}{|c|c|c|c|}
\hline Characteristic & 1 & 2 & 3 \\
\hline \multicolumn{4}{|l|}{ Cell dimensions $(\mu \mathrm{m})$} \\
\hline Width & $0.5-0.9$ & $1.0-1.5$ & $0.5-0.7^{\star}$ \\
\hline Length & $1.2-2.5$ & $2.5-3.0$ & $1.3-1.9^{*}$ \\
\hline Pigmentation $\dagger$ & C & C & $\mathrm{CW}$ to $\mathrm{Y}$ \\
\hline Endospore position/shape $\ddagger$ & CST/E & CST/E & $\mathrm{T} / \mathrm{S}$ \\
\hline Motility & + & + & - \\
\hline \multicolumn{4}{|l|}{$\mathrm{NaCl}$ concentration $(\%, \mathrm{w} / \mathrm{v})$} \\
\hline Range & $2.5-15$ & $5-20$ & $3-20$ \\
\hline Optimum & $5-7.5$ & 10 & $10-12$ \\
\hline \multicolumn{4}{|l|}{ Temperature $\left({ }^{\circ} \mathrm{C}\right)$} \\
\hline Range & $25-45$ & $25-45$ & $15-40^{*}$ \\
\hline Optimum & 35 & 40 & $30^{*}$ \\
\hline \multicolumn{4}{|l|}{$\mathrm{pH}$} \\
\hline Range & $7-10$ & $7-10$ & $6.8-9.5^{\star}$ \\
\hline Optimum & 7.5 & $8.0-8.5$ & $8.0^{*}$ \\
\hline Nitrate reduction & + & - & - \\
\hline \multicolumn{4}{|l|}{ Hydrolysis of: } \\
\hline Tween 80 & - & + & - \\
\hline Casein & - & + & - \\
\hline Aesculin & - & - & + \\
\hline \multicolumn{4}{|l|}{ Acid production from: } \\
\hline D-Glucose & - & + & + \\
\hline D-Galactose & - & - & + \\
\hline D-Fructose & - & - & + \\
\hline Lactose & - & - & + \\
\hline Maltose & - & - & + \\
\hline D-Mannitol & + & - & + \\
\hline D-Xylose & - & - & + \\
\hline Quinones & $\begin{array}{c}\text { MK-7, MK- } \\
\text { 6, MK-5 }\end{array}$ & MK-7 & MK-7* \\
\hline DNA G $+\mathrm{C}$ content $(\mathrm{mol} \%)$ & 42.4 & 37.1 & $43^{*}$ \\
\hline
\end{tabular}

${ }^{\star}$ Data were taken from Lim et al. (2006c).

$\dagger \mathrm{C}$, Cream; CW, cream-white; y, yellow.

‡CST/E, Central-subterminal/ellipsoidal; T/s, terminal/spherical. 
and phylogenetic analysis. The identification of phylogenetic neighbours and calculation of pairwise 16S rRNA gene sequence similarity were achieved using the EzTaxon-e server (http://eztaxon-e.ezbiocloud.net; Kim et al., 2012). Sequence analysis was performed using the ARB software package (Ludwig et al., 2004). The $16 \mathrm{~S}$ rRNA gene sequence was aligned with published sequences of closely related bacteria and the alignment was confirmed and checked against both primary and secondary structures of the 16S rRNA molecule using the alignment tool of the ARB software package. Phylogenetic trees were reconstructed using the maximum-likelihood (Felsenstein, 1981), maximum-parsimony (Fitch, 1971) and neighbour-joining (Saitou \& Nei, 1987) algorithms in the ARB software.

The closest relative of strain $\mathrm{X}_{5} \mathrm{~B}^{\mathrm{T}}$ was $B$. persepolensis HS $136^{\mathrm{T}}$ (95.6 \% 16S rRNA gene sequence similarity). Other strains closely related to strain $\mathrm{X}^{\mathrm{B}} \mathrm{B}^{\mathrm{T}}$ were B. salarius $\mathrm{BH} 169^{\mathrm{T}}$ (95.5\%), Bacillus aidingensis $17-5^{\mathrm{T}}(94.8 \%)$ and Bacillus qingdaonensis $\mathrm{CM1}^{\mathrm{T}}(94.3 \%) .16 \mathrm{~S}$ rRNA gene sequence similarity between strain $\mathrm{X}_{5} \mathrm{~B}^{\mathrm{T}}$ and other Gram-positive endospore-forming bacilli was $<94 \%$. The three treeing algorithms resulted in phylogenetic trees with similar topologies (Fig. 1 and Supplementary Figs S1 and S2, available in IJSEM Online). On the basis of sequence divergence, it was evident that strain $\mathrm{X}^{\mathrm{B}} \mathrm{B}^{\mathrm{T}}$ constituted a taxon separate from the other known species of the genus Bacillus. DNA-DNA hybridization between strain $\mathrm{X}^{\mathrm{B}} \mathrm{B}^{\mathrm{T}}$ and its nearest phylogenetic neighbours was not done since strains exhibiting $<97 \% 16 \mathrm{~S}$ rRNA gene sequence similarity are unlikely to exhibit $>70 \%$ DNA-DNA relatedness at the whole-genome level, a criteria necessary for the delineation of separate species (Stackebrandt \& Goebel, 1994; Stackebrandt et al., 2002).
To determine the DNA base composition, DNA was isolated using a French pressure cell (Thermo Spectronic) and purified by chromatography on hydroxyapatite as described by Cashion et al. (1977). The DNA G+C content was determined by reversed-phase HPLC of nucleosides according to Mesbah et al. (1989). The G $+\mathrm{C}$ content of the DNA of strain $\mathrm{X} \mathrm{B}^{\mathrm{T}}$ was $42.4 \mathrm{~mol} \%$. This value is within the range for the genus Bacillus and similar to that of the type species of the genus, Bacillus subtilis (42.9 mol\%; Logan \& De Vos, 2009); however, the $G+C$ content of the DNA of strain $X 5 B^{T}$ was higher than that of B. persepolensis IBRC $10436^{\mathrm{T}}$ and slightly lower than that of B. salarius DSM $16461^{\mathrm{T}}$ (Table 1).

Cell biomass for analysis of the cell-wall peptidoglycan, polar lipids and isoprenoid quinones was obtained by cultivation on $7.5 \% \mathrm{HM}$ agar at $35{ }^{\circ} \mathrm{C}$. Whole-cell hydrolysates $\left(100{ }^{\circ} \mathrm{C}, 4 \mathrm{M} \mathrm{HCl}, 16 \mathrm{~h}\right)$ were examined for diaminopimelic acid isomers by TLC on cellulose plates using the solvent system of Rhuland et al. (1955). Polar lipids were analysed as described by Groth et al. (1996) and isoprenoid quinones were analysed as described by Monciardini et al. (2003).

The cell-wall peptidoglycan was based on meso-diaminopimelic acid and the polar lipids detected were phosphatidylglycerol, diphosphatidylglycerol, three phospholipids and two glycolipids (Supplementary Fig. S3). The isolate displayed a complex polar lipid profile similar to that of $B$. subtilis (Kämpfer et al., 2006), while B. persepolensis displayed a simple polar lipid pattern consisting of phosphatidylglycerol and diphosphatidylglycerol (Amoozegar et al., 2009). However, phosphatidylethanolamine, which has been reported for B. subtilis, was not detected in strain $\mathrm{X}^{\mathrm{B}} \mathrm{B}^{\mathrm{T}}$ or B. persepolensis (Amoozegar et al., 2009; Kämpfer et al., 2006). The major isoprenoid quinone of strain $X 5 B^{T}$ was

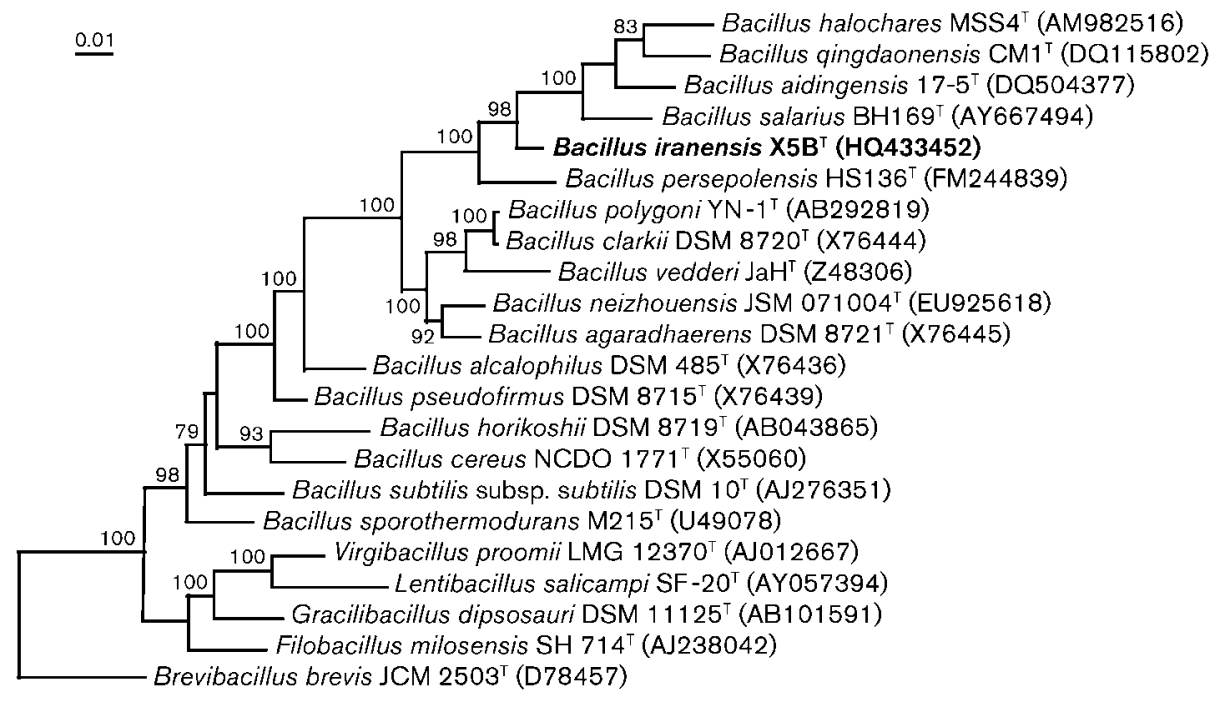

Fig. 1. Maximum-likelihood phylogenetic tree based on 16S rRNA gene sequences showing the relationships between strain $\mathrm{X} \mathrm{B}^{\top}$ and closely related type strains of species of the genus Bacillus. Bootstrap values $(>70 \%)$ based on 1000 replications are given at branch nodes. Brevibacillus brevis JCM $2503^{\top}$ was used as an outgroup. Bar, 0.01 substitutions per nucleotide position. 
MK-7 (92\%), which is typical of the genus Bacillus, and MK6 and MK-5 were also present (6 and $2 \%$, respectively). In summary, the data for the respiratory quinones, polar lipids and the peptidoglycan type of the cell wall of strain $\mathrm{X}^{\mathrm{B}} \mathrm{B}^{\mathrm{T}}$ were typical for members of the genus Bacillus (Priest et al., 1988; Heyrman et al., 2004, 2005; Wieser et al., 2005; Lim et al., 2006a, b, c).

Whole-cell fatty acid composition was determined by GC using the Microbial Identification System (MIDI version 6.1, identification library TSBA40 4.1; Microbial ID). Cells were cultured on marine agar (Difco) containing $5 \%(\mathrm{w} / \mathrm{v})$ $\mathrm{NaCl}$ at $30{ }^{\circ} \mathrm{C}$ for $48 \mathrm{~h}$. The cellular fatty acid composition of strain $\mathrm{X}_{5} \mathrm{~B}^{\mathrm{T}}$ was characterized by the major fatty acids anteiso- $\mathrm{C}_{15: 0}(43.4 \%)$ and iso- $\mathrm{C}_{15: 0}(21.8 \%)$. The fatty acid composition was similar to that of $B$. persepolensis IBRC $10436^{\mathrm{T}}$ except that strain $\mathrm{X} \mathrm{B}^{\mathrm{T}}$ contained higher proportions of anteiso- $\mathrm{C}_{17: 0}$ and iso- $\mathrm{C}_{17: 0}$ and also contained $\mathrm{C}_{18: 1} \omega 9 c$ (Table 2).

The isolate could be distinguished from closely related members of the genus Bacillus by a combination of differences in endospore shape and position, motility, $\mathrm{NaCl}$ range and optimum for growth, acid production from carbohydrates, nitrate reduction and other phenotypic tests, as well as by the genomic DNA G + C content. The fatty acid composition could also be used to distinguish strain $\mathrm{X}_{5} \mathrm{~B}^{\mathrm{T}}$ from phylogenetically related taxa. Therefore, we propose that the isolate represents a novel species of the genus Bacillus, for which the name $B$. iranensis sp. nov. is proposed.

\section{Description of Bacillus iranensis sp. nov.}

Bacillus iranensis (i.ra.nen'sis. N.L. masc. adj. iranensis from Iran, where the type strain was isolated).

Cells are Gram-positive, motile, endospore-forming rods $(0.5-0.9 \times 1.2-2.5 \mu \mathrm{m})$. Ellipsoidal endospores are produced at a central-subterminal position in non-swollen sporangia.

Table 2. Cellular fatty acid compositions of strain $X 5 B^{\top}$ and its closest phylogenetic neighbours

Strains: 1, Bacillus iranensis sp. nov. $\mathrm{X}^{\mathrm{B}} \mathrm{B}^{\mathrm{T}} ; 2$, B. persepolensis IBRC $10436^{\mathrm{T}}$; 3, B. salarius DSM $16461^{\mathrm{T}}$. Data were taken from this study under the same conditions.

\begin{tabular}{|lrcc|}
\hline Fatty acid (\%) & $\mathbf{1}$ & $\mathbf{2}$ & $\mathbf{3}$ \\
\hline iso- $\mathrm{C}_{14: 0}$ & 0.5 & 0.9 & 2.4 \\
$\mathrm{C}_{14: 0}$ & 1.2 & 1.0 & 1.0 \\
iso- $_{15: 0}$ & 21.8 & 62.0 & 7.8 \\
anteiso-C $_{15: 0}$ & 43.4 & 21.0 & 49.7 \\
iso-C $\mathrm{C}_{16: 0}$ & 1.6 & 1.4 & 6.8 \\
$\mathrm{C}_{16: 0}$ & 7.9 & 3.6 & 5.5 \\
iso- $_{17: 0}$ & 10.2 & 3.9 & 3.4 \\
anteiso-C & 9.4 & 3.5 & 18.9 \\
$\mathrm{C}_{16: 1} \omega 11 c$ & 0.8 & 2.0 & 0.5 \\
$\mathrm{C}_{18: 1} \omega 9 c$ & 8.0 & - & - \\
\hline
\end{tabular}

Colonies are circular, entire, smooth, cream and $2 \mathrm{~mm}$ in diameter after $48 \mathrm{~h}$ at $35{ }^{\circ} \mathrm{C}$ on $7.5 \% \mathrm{HM}$ agar. Strictly aerobic. Moderately halophilic; grows with $2.5-15 \%(w / v)$ $\mathrm{NaCl}$ (optimum 5-7.5\%), but not without $\mathrm{NaCl}$. Grows at $25-45{ }^{\circ} \mathrm{C}$ (optimum $35{ }^{\circ} \mathrm{C}$ ) and $\mathrm{pH}$ 7.0-10.0 (optimum $\mathrm{pH}$ 7.5). Catalase- and oxidase-positive. Casein, gelatin, DNA, starch and Tweens 40, 60 and 80 are not hydrolysed. Nitrate is reduced to nitrite, but nitrite is not reduced. Indole and $\mathrm{H}_{2} \mathrm{~S}$ are not produced. Acid is produced from Dmannitol, but not from D-glucose, D-fructose, galactose, lactose, sucrose, maltose, trehalose, D-mannose or D-xylose. Methyl red, Voges-Proskauer, urease, $\beta$-galactosidase, lysine decarboxylase, ornithine decarboxylase and arginine dihydrolase tests are negative. The following compounds are utilized as sole source of carbon and energy: D-fructose, cellobiose and alanine. The following compounds are not utilized as sole source of carbon and energy: D-glucose, galactose, D-mannose, melibiose, sucrose, glycerol, trehalose, raffinose, arabinose, arginine, glycine, leucine, methionine, proline, cysteine, asparagine, tyrosine, histidine and valine. Sensitive to ( $\mu \mathrm{g}$ per disc unless otherwise stated) bacitracin (10 U), chloramphenicol (30), erythromycin (15), nitrofurantoin (300), penicillin $\mathrm{G}$ (10 U), tetracycline (30) and rifampicin (5); resistant to gentamicin (30), kanamycin (30) and polymyxin $\mathrm{B}(100 \mathrm{U})$. The diamino acid in the cell-wall peptidoglycan is meso-diaminopimelic acid. The polar lipids are phosphatidylglycerol, diphosphatidylglycerol, three phospholipids and two glycolipids. The isoprenoid quinones are MK-7, MK-6 and MK-5. The predominant cellular fatty acids $(>5 \%)$ are anteiso- $\mathrm{C}_{15: 0}$, iso- $\mathrm{C}_{15: 0}$, iso- $\mathrm{C}_{17: 0}$, anteiso$\mathrm{C}_{17: 0}, \mathrm{C}_{18: 1} \omega 9 c$ and $\mathrm{C}_{16: 0}$. The DNA G+C content of the type strain is $42.4 \mathrm{~mol} \%$ (HPLC).

The type strain is $\mathrm{X}^{2} \mathrm{~B}^{\mathrm{T}}\left(=\mathrm{IBRC} 10446^{\mathrm{T}}=\mathrm{DSM} 23995^{\mathrm{T}}\right)$, isolated from the hypersaline lake Aran-Bidgol in Iran.

\section{Acknowledgements}

This work was supported by grants from the Iranian Biological Resource Centre (IBRC) (MI-1388-04) and the International Foundation for Science (IFS) (A/4527-1) to M.A. Amoozegar and the Spanish Ministerio de Economía y Competitividad (CGL201019303) that include European Funds (FEDER), the National Science Foundation (DEB-0919290) and the Junta de Andalucía (P10-CVI6226) to A. Ventosa.

\section{References}

Amoozegar, M. A., Salehghamari, E., Khajeh, K., Kabiri, M. \& Naddaf, S. (2008). Production of an extracellular thermohalophilic lipase from a moderately halophilic bacterium, Salinivibrio sp. strain SA-2. J Basic Microbiol 48, 160-167.

Amoozegar, M. A., Sánchez-Porro, C., Rohban, R., Hajighasemi, M. \& Ventosa, A. (2009). Bacillus persepolensis sp. nov., a moderately halophilic bacterium from a hypersaline lake. Int J Syst Evol Microbiol 59, 2352-2358.

Arahal, D. R. \& Ventosa, A. (2002). Moderately halophilic and halotolerant species of Bacillus and related genera. In Applications and Systematics of Bacillus and Relatives, pp. 83-99. Edited by R. Berkeley, M. Heyndrickx, N. Logan \& P. De Vos. Oxford: Blackwell. 
Baron, E. J. \& Finegold, S. M. (1990). Bailey and Scott's Diagnostic Microbiology, 8th edn. St Louis, MO: Mosby.

Cashion, P., Holder-Franklin, M. A., McCully, J. \& Franklin, M. (1977). A rapid method for the base ratio determination of bacterial DNA. Anal Biochem 81, 461-466.

de la Haba, R. R., Sánchez-Porro, C., Márquez, M. C. \& Ventosa, A. (2011). Taxonomy of halophiles. In Extremophiles Handbook, pp. 255-308. Edited by K. Horikoshi. Tokyo: Springer.

Felsenstein, J. (1981). Evolutionary trees from DNA sequences: a maximum likelihood approach. J Mol Evol 17, 368-376.

Fitch, W. M. (1971). Toward defining the course of evolution: minimum change for a specific tree topology. Syst Zool 20, 406-416.

Groth, I., Schumann, P., Weiss, N., Martin, K. \& Rainey, F. A. (1996). Agrococcus jenensis gen. nov., sp. nov., a new genus of actinomycetes with diaminobutyric acid in the cell wall. Int J Syst Bacteriol 46, 234239.

Harrigan, W. F. \& McCance, M. E. (1976). Laboratory Methods in Food and Dairy Microbiology. London: Academic Press.

Heyrman, J., Vanparys, B., Logan, N. A., Balcaen, A., Rodríguez-Díaz, M., Felske, A. \& De Vos, P. (2004). Bacillus novalis sp. nov., Bacillus vireti sp. nov., Bacillus soli sp. nov., Bacillus bataviensis sp. nov. and Bacillus drentensis sp. nov., from the Drentse A grasslands. Int J Syst Evol Microbiol 54, 47-57.

Heyrman, J., Rodríguez-Díaz, M., Devos, J., Felske, A., Logan, N. A. \& De Vos, P. (2005). Bacillus arenosi sp. nov., Bacillus arvi sp. nov. and Bacillus humi sp. nov., isolated from soil. Int J Syst Evol Microbiol 55, 111-117.

Kämpfer, P., Rosselló-Mora, R., Falsen, E., Busse, H.-J. \& Tindall, B. J. (2006). Cohnella thermotolerans gen. nov., sp. nov., and classification of 'Paenibacillus hongkongensis' as Cohnella hongkongensis sp. nov. Int J Syst Evol Microbiol 56, 781-786.

Karbalaei-Heidari, H. R., Amoozegar, M. A., Hajighasemi, M., Ziaee, A. A. \& Ventosa, A. (2009). Production, optimization and purification of a novel extracellular protease from the moderately halophilic bacterium Halobacillus karajensis. J Ind Microbiol Biotechnol 36, 2127.

Kim, O. S., Cho, Y.-J., Lee, K., Yoon, S.-H., Kim, M., Na, H., Park, S.-C., Jeon, Y.S., Lee, J.-H., Yi, H., Won, S. \& Chun, J. (2012). Introducing EzTaxon-e: a prokaryotic $16 \mathrm{~S}$ rRNA gene sequence database with phylotypes that represent uncultured species. Int J Syst Evol Microbiol 62, 716-721.

Kiran, K. K. \& Chandra, T. S. (2008). Production of surfactant and detergent-stable, halophilic, and alkalitolerant alpha-amylase by a moderately halophilic Bacillus sp. strain TSCVKK. Appl Microbiol Biotechnol 77, 1023-1031.

Lim, J.-M., Jeon, C. O. \& Kim, C.-J. (2006a). Bacillus taeanensis sp. nov., a halophilic Gram-positive bacterium from a solar saltern in Korea. Int J Syst Evol Microbiol 56, 2903-2908.

Lim, J.-M., Jeon, C. O., Lee, J.-C., Ju, Y. J., Park, D.-J. \& Kim, C.-J. (2006b). Bacillus koreensis sp. nov., a spore-forming bacterium, isolated from the rhizosphere of willow roots in Korea. Int J Syst Evol Microbiol 56, 59-63.

Lim, J.-M., Jeon, C. O., Lee, S.-M., Lee, J.-C., Xu, L.-H., Jiang, C.-L. \& Kim, C.-J. (2006c). Bacillus salarius sp. nov., a halophilic, sporeforming bacterium isolated from a salt lake in China. Int J Syst Evol Microbiol 56, 373-377.

Logan, N. A. \& De Vos, P. (2009). Genus I. Bacillus. In Bergey's Manual of Systematic Bacteriology, The Firmicutes, vol. 3, pp. 21-128. Edited by P. De Vos, G. M. Garrity, D. Jones, N. R. Krieg, W. Ludwig, F. A. Rainey, K.-H. Schleifer \& W. B. Whitman. New York: Springer.
Logan, N. A., Berge, O., Bishop, A. H., Busse, H.-J., De Vos, P., Fritze, D., Heyndrickx, M., Kämpfer, P., Rabinovitch, L. \& other authors (2009). Proposed minimal standards for describing new taxa of aerobic, endospore-forming bacteria. Int J Syst Evol Microbiol 59, 2114-2121.

Ludwig, W., Strunk, O., Westram, R., Richter, L., Meier, H., Yadhukumar, Buchner, A., Lai, T., Steppi, S. \& other authors (2004). ARB: a software environment for sequence data. Nucleic Acids Res 32, 1363-1371.

Margesin, R. \& Schinner, F. (2001). Potential of halotolerant and halophilic microorganisms for biotechnology. Extremophiles 5, 73-83.

Marmur, J. (1961). A procedure for the isolation of deoxyribonucleic acid from micro-organisms. J Mol Biol 3, 208-218.

Márquez, M. C., Sánchez-Porro, C. \& Ventosa, A. (2011). Halophilic and haloalkaliphilic, aerobic endospore-forming bacteria in soil. In Endospore-forming Soil Bacteria, pp. 309-339. Edited by N. A. Logan \& P. De Vos. Berlin: Springer.

Mata, J. A., Martínez-Cánovas, J., Quesada, E. \& Béjar, V. (2002). A detailed phenotypic characterisation of the type strains of Halomonas species. Syst Appl Microbiol 25, 360-375.

Mellado, E., Moore, E. R. B., Nieto, J. J. \& Ventosa, A. (1995). Phylogenetic and taxonomic consequences of $16 \mathrm{~S}$ ribosomal DNA sequence comparison of Chromohalobacter marismortui, Volcaniella eurihalina and Deleya salina, and reclassification of $V$. eurihalina as Halomonas eurihalina comb. nov. Int J Syst Bacteriol 45, 712-716.

Mellado, M. E. \& Ventosa, A. (2003). Biotechnological potential of moderately and extremely halophilic microorganisms. In Microorganisms for Health Care, Food and Enzyme Production, pp. 233-256. Edited by J. L. Barredo. Kerala: Research Signpost.

Mesbah, M., Premachandran, U. \& Whitman, W. B. (1989). Precise measurement of the $\mathrm{G}+\mathrm{C}$ content of deoxyribonucleic acid by highperformance liquid chromatography. Int J Syst Bacteriol 39, 159-167.

Monciardini, P., Cavaletti, L., Schumann, P., Rohde, M. \& Donadio, S. (2003). Conexibacter woesei gen. nov., sp. nov., a novel representative of a deep evolutionary line of descent within the class Actinobacteria. Int J Syst Evol Microbiol 53, 569-576.

Murray, R. G. E., Doetsch, R. N. \& Robinow, C. F. (1994). Determinative and cytological light microscopy. In Methods for General and Molecular Bacteriology, pp. 21-41. Edited by P. Gerhardt, R. G. E. Murray, W. A. Wood \& N. R. Krieg. Washington, DC: American Society for Microbiology.

Priest, F. G., Goodfellow, M. \& Todd, C. (1988). A numerical classification of the genus Bacillus. J Gen Microbiol 134, 1847-1882.

Quesada, E., Ventosa, A., Ruiz-Berraquero, F. \& RamosCormenzana, A. (1984). Deleya halophila, a new species of moderately halophilic bacteria. Int J Syst Bacteriol 34, 287-292.

Rhuland, L. E., Work, E., Denman, R. F. \& Hoare, D. S. (1955). The behavior of the isomers of $\alpha, \varepsilon$-diaminopimelic acid on paper chromatograms. J Am Chem Soc 77, 4844-4846.

Rohban, R., Amoozegar, M. A. \& Ventosa, A. (2009). Screening and isolation of halophilic bacteria producing extracellular hydrolyses from Howz Soltan Lake, Iran. J Ind Microbiol Biotechnol 36, 333-340.

Saitou, N. \& Nei, M. (1987). The neighbor-joining method: a new method for reconstructing phylogenetic trees. Mol Biol Evol 4, 406425.

Sánchez-Porro, C., Martín, S., Mellado, E. \& Ventosa, A. (2003). Diversity of moderately halophilic bacteria producing extracellular hydrolytic enzymes. J Appl Microbiol 94, 295-300.

Shafiei, M., Ziaee, A. \& Amoozegar, M. A. (2010). Purification and biochemical characterization of a novel SDS and surfactant stable, raw starch digesting, and halophilic $\alpha$-amylase from a moderately 
halophilic bacterium, Nesterenkonia sp. strain F. Process Biochem 45, 694-699.

Smibert, R. M. \& Krieg, N. R. (1994). Phenotypic characterization. In Methods for General and Molecular Bacteriology, pp. 607-654. Edited by P. Gerhardt, R. G. E. Murray, W. A. Wood \& N. R. Krieg. Washington, DC: American Society for Microbiology.

Stackebrandt, E. \& Goebel, B. M. (1994). Taxonomic note: a place for DNA-DNA reassociation and $16 \mathrm{~S}$ rRNA sequence analysis in the present species definition in bacteriology. Int J Syst Bacteriol 44, 846849.

Stackebrandt, E., Frederiksen, W., Garrity, G. M., Grimont, P. A. D., Kämpfer, P., Maiden, M. C. J., Nesme, X., Rosselló-Mora, R., Swings, J. \& other authors (2002). Report of the ad hoc committee for the re-evaluation of the species definition in bacteriology. Int J Syst Evol Microbiol 52, 1043-1047.

Ventosa, A. (2006). Unusual micro-organisms from unusual habitats: hypersaline environments. In Prokaryotic diversity: mechanisms and significance, pp. 223-254. Edited by N. A. Logan, H. M. Lappin-Scott \& P. C. F. Oyston. Cambridge: Cambridge University Press.

Ventosa, A., Quesada, E., Rodriguez-Valera, F., Ruiz-Berraquero, F. \& Ramos-Cormenzana, A. (1982). Numerical taxonomy of moderately halophilic Gram-negative rods. J Gen Microbiol 128, 1959-1968.

Ventosa, A., Nieto, J. J. \& Oren, A. (1998). Biology of moderately halophilic aerobic bacteria. Microbiol Mol Biol Rev 62, 504-544.

Wieser, M., Worliczek, H., Kämpfer, P. \& Busse, H.-J. (2005). Bacillus herbersteinensis sp. nov. Int J Syst Evol Microbiol 55, 2119-2123. 